\title{
Hydrological Simulation of Runoff for a Watershed in Punpun Basin using SWAT
}

\author{
Aditya Shekhar, Subha Sinha
}

\begin{abstract}
Runoff is a very important phenomenon of hydrological cycle and it is relevant for the watershed management programme for conservation and development or natural resources and its management. However, In India the availability of accurate information on runoff is very scarce and needs to be calculated empirically for further developments. The Soil and Water Assessment Tool (SWAT) is a physical parameter model which has been developed to estimate values for the runoff, sediment and nutrient carry off from the agricultural watersheds under various distinct land management practices. For the present study, a small agricultural watershed has been selected for runoff assessment. Watershed is considered to be the ideal unit for management of the natural resources. Extraction of watershed parameters using Remote Sensing and Geographical Information System (GIS) and use of mathematical models is one of the current trends for hydrologic evaluation of these watersheds monitored.

The Soil and Water Assessment Tool (SWAT) having an interface with Quantum GIS (QGIS) software (QSWAT version 1.3) was selected for the estimation of surface runoff from an area of Punpun basin near Patna an intermediate watershed of Punpun river, located in southern Bihar region. Maps of the region obtained from the Bihar Remote Sensing Application Centre (BIRSAC) were used for computation. The model was run and validated with the observed runoff and for the years 2005-2010. The performance of the model was evaluated using statistical and graphical methods to assess the capability of the model in simulating the surface runoff from the study area. According to the model estimates, the value for the surface runoff was maximum for the year 2007 as $710 \mathrm{~mm}$ and was minimum for the year 2005 with about $185 \mathrm{~mm}$. As per the observed values of discharge from the Central Water Commission (CWC), the values for surface runoff for these years were different by about 10 to $11 \%$.
\end{abstract}

Keywords: Surface Runoff, QGIS, DEM, SWAT.

\section{INTRODUCTION}

Surface runoff is a crucial to be estimated for a better resource management and to promote a sustainable environment. It's one of the main reasons for soil erosion and hence its simulation becomes important to help making some

Revised Manuscript Received on July 20, 2020.

* Correspondence Author

Aditya Shekhar, Department of Civil Engineering, IIT Kanpur, U.P., India. E-mail: sardi@iitk.ac.in

Subha Sinha*, Department of Civil Engineering, Department, M.I.T. Muzaffarpur, Bihar, India. E-mail: starsubha@gamil.com

(C) The Authors. Published by Blue Eyes Intelligence Engineering and Sciences Publication (BEIESP). This is an open access article under the CC BY-NC-ND license (http://creativecommons.org/licenses/by-nc-nd/4.0/) reliable land use and land management practices [1]. Floods have been common occurrence in the Punpun basin situated in Bihar, India that makes it vital to have a close estimation of hydrological parameters that are the main cause [2]. Today, Mathematical models are being used to evaluate parameters like Runoff, Soil erosion, Sediment yield, prompt overflow and other important values that defines the area in terms of its water intake or release. Interpretation with GIS technology helps to generate accurate runoff models. Various models like Water Erosion Prediction Project (WEPP), Limberg Soil Erosion model (LISEM) etc. have been commonly used nowadays like researchers to simulate values for these parameters. The SWAT (Soil and water assessment tool) model has been checked by many different authors and validation have been published for various basins. SWAT 2005 was selected for the present study and a 5-year simulation was performed for a small watershed inside the huge Punpun basin, situated in the state of Bihar.

\section{STUDY AREA AND DATA COLLECTION}

\section{Study Area}

\section{a) Description of location}

Punpun River is one of the important river bank tributaries of the Ganga River. It originates from the Chottanagpur hills of Palamau district at an elevation of $300 \mathrm{~m}$ in Bihar. The length of the river is $200 \mathrm{~km}$ and it is mostly rain fed and carries minimal discharge during non-monsoon period. It often causes heavy flood damages on the eastwards side of the Patna city. Roughly trapezoid in shape, the catchment length is about $180 \mathrm{~km}$ and average widths in the upper and lower reaches are $60 \mathrm{~km}$ and $25 \mathrm{~km}$ respectively. The catchment area of the basin is about $8,500 \mathrm{~km}^{2}$. This is $1 \%$ of the total area of Ganga basin in the country. A watershed has been selected near the Patna district and the surface runoff modeling has been done for the same. The figure 2 shows the watershed area selected. The watershed number 24 as per the nomenclature done in boundary generation was selected for SWAT modeling. The area of the watershed is $720 \mathrm{sq}$ kilometers and extension is: South Latitude: 25.28464 degrees; NWest Longitude: 84.76438 degrees E; North Latitude: 25.559372 degrees; NEast Longitude: 85.304751 degrees $\mathrm{E}$.

\section{b) Hydrology of the Region}

The Lower Ganga plain system consists of the tributaries as well as the distributaries of the main Ganga. Bhagirathi and Padma comprise of the important ones.

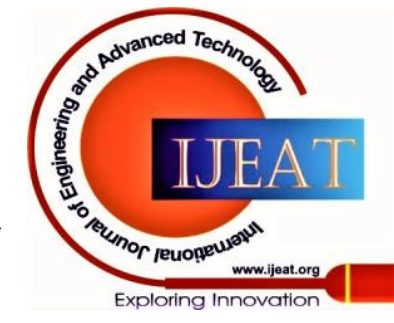




\section{Hydrological Simulation of Runoff for a Watershed in Punpun Basin using SWAT}

The Hoogly-Bhagirathi is the main stream that goes to meet the Bay of Bengal adjacent to Sagar Island. A voluminous discharge is seen in the region to adjoining basins.

\section{Data Collection}

\section{a) Dem Data}

A DEM (digital elevation model) is a three-dimensional representation of the surface of the terrain. This is generally used for a planet (say earth) moon, other objects. The elevation data for terrain is utilized for its generation. Figure 1 represents the DEM map for the watershed or study region. Data providers like USGS, CGIAR and others use the term DEM as generic one for DSM and DTM. Li et al., 2005 state that it is possible to have compute DTM from a high-resolution DSM dataset using some complex algorithm for it. In general, DEM can be seen as a subset of the DTM.

\section{b) Obtaining SRTM Data}

SRTM (Shuttle Radar Tomography Mission) is a nice source for getting the Digital elevation model, possibly in most regions of the world. It provides both $90 \mathrm{~m}$ and $30 \mathrm{~m}$ resolutions. The extent of watershed to be modeled was first selected and then the clipping was done on basis on the decimal degrees. The maximum and mean elevation for the area is as below: Maximum elevation: $78 \mathrm{~m}$, Mean elevation: $41.62 \mathrm{~m}$.

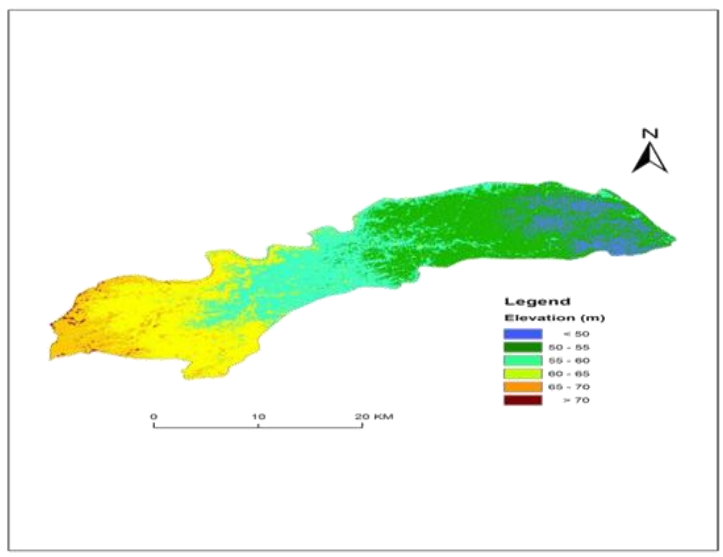

Fig.1. DEM Map for the Watershed

\section{c) Soil Data}

The soil map for the area was obtained from the BIRSAC (Bihar Remote Sensing Application centre) for the area to be worked on for SWAT modeling. The geology of the area varies from granite, gneiss, and charnokites in the hills to the recent alluvium in the plains. The broad soil groups are calcium and non-calcium, recent and old alluvium and brown forest soils, red soil podzowe, lateritic soils with cover being very deep in plains and deep to shallow in hills. Soil map is shown in Fig. 2.

\section{d) Landuse Data}

As for soil data, this information was also obtained with the help of BIRSAC. The land use pattern of the watershed shows that out of the total area of $720 \mathrm{~km}^{2}$, about $658 \mathrm{~km}^{2}$ is under agriculture, $48 \mathrm{~km}^{2}$ is under urban occupation, and the remaining area of $14 \mathrm{~km}^{2}$ is under wastelands and waterbodies. The pattern for landuse is depicted in Table No.2 and the map for Landuse is shown in Fig. 3. The length of the main channel of Punpun basin is $232 \mathrm{~km}$. Drainage density (total length of channels of all order to the total area of the basin) is $0.377 \mathrm{~km} / \mathrm{km}^{2}$. The various landuses for the study area are mentioned in Table 1.

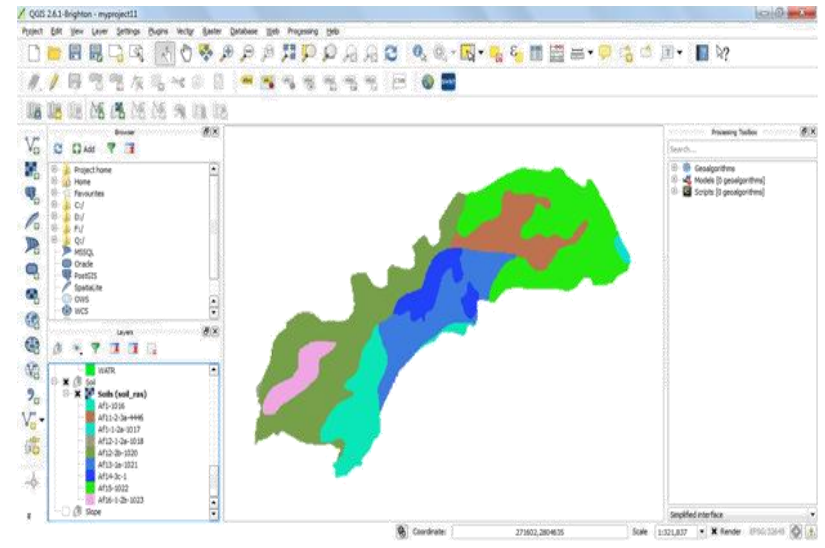

Fig. 2. Soil Map for the Watershed

\section{e) Weather Data}

The weather data was taken for the Patna weather station with the help of data from the IMD (Indian meteorological department) in form of an excel file as per requirements of simulation. The data comprises of: Maximum temperature (In degree Celsius), Minimum temperature (In degree Celsius), Wind speed (In kmph), Relative Humidity (In Percent), Precipitation (In mm), Solar Intensity $\left(\mathrm{kw} / \mathrm{m}^{2}\right)$.

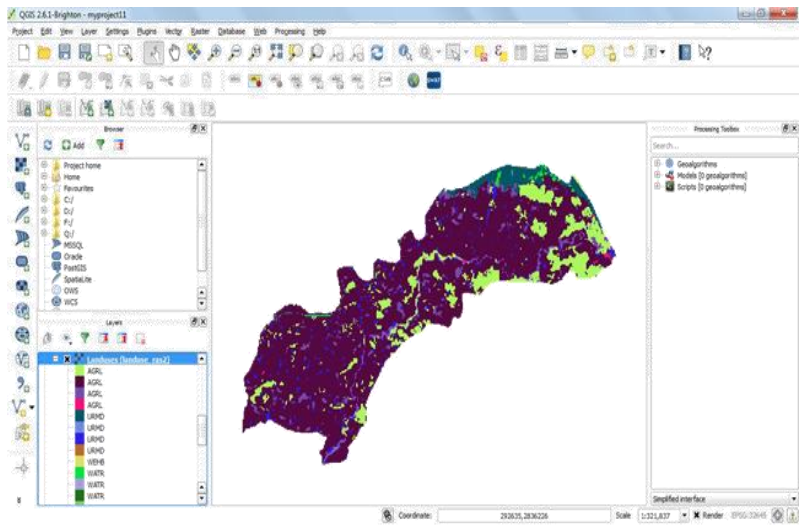

Fig.3. Landuse Map

\section{METHODOLOGY AND MODEL DISCRIPTION}

SWAT model divides the watershed into various small sub-watersheds, which are then further subdivide in HRUs (Hydrologic response units) which consist of homogeneous land use, land management, soil characteristic along with the weather and topographical data as shown in flow diagram below. HRUs depict percent of sub-watershed area that may be or may not be defined spatially in the SWAT simulation. Following Figure 4 shows the flow diagram [3] of SWAT model simulation.

The basin boundary was generated with the help of Goggle Earth Pro. The QGIS Software along with the QSWAT plugin helped for the SWAT output visualization. Basic procedure as per QSWAT manual was used ( https://swat.tamu.edu ).

Published By:

Blue Eyes Intelligence Engineering and Sciences Publication

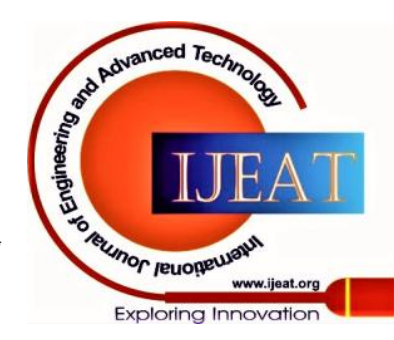




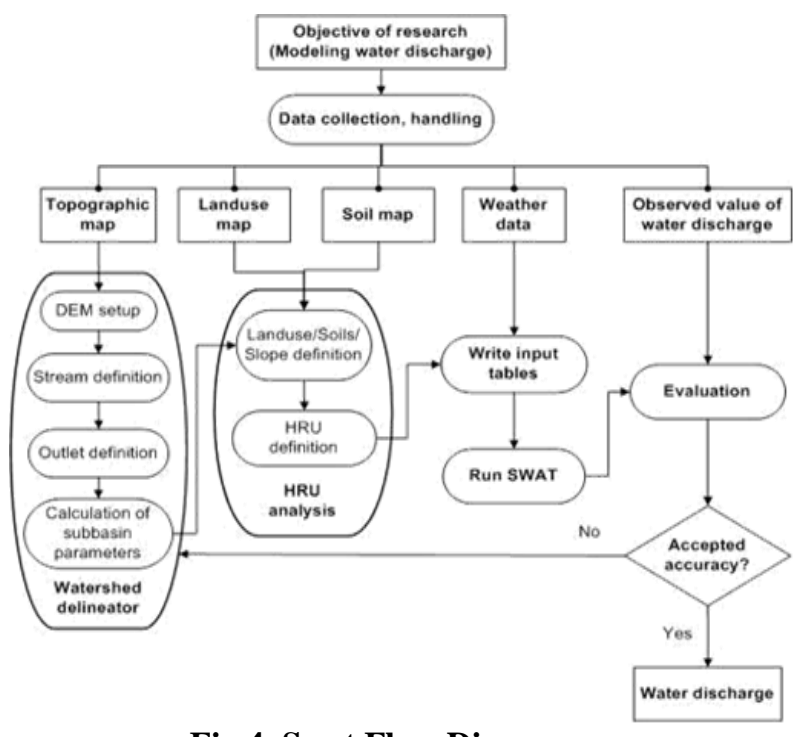

Fig.4. Swat Flow Diagram

\begin{tabular}{|l|r|r|}
\hline \multicolumn{1}{|c|}{ LAND USE/LAND COVER } & \multicolumn{1}{|c|}{$\begin{array}{c}\text { Area } \\
\left.\mathbf{( k m}^{2}\right)\end{array}$} & \multicolumn{1}{|c|}{$\begin{array}{c}\text { Area } \\
(\mathbf{\%})\end{array}$} \\
\hline $\begin{array}{l}\text { Agricultural Land-Crop Land-Rabi } \\
\text { Crop(AGRL) }\end{array}$ & 91.01 & 12.65 \\
\hline $\begin{array}{l}\text { Agricultural Land-Crop Land-Two crop } \\
\text { area(AGRL) }\end{array}$ & 534.72 & 74.3 \\
\hline $\begin{array}{l}\text { Agricultural Land-Fallow-Current } \\
\text { Fallow(AGRL) }\end{array}$ & 31.47 & 4.37 \\
\hline $\begin{array}{l}\text { Agricultural Land-Plantation-Horticulture } \\
\text { Plant(AGRL) }\end{array}$ & 1.22 & 0.17 \\
\hline $\begin{array}{l}\text { Built Up-Built Up (Urban)-Mixed Built Up } \\
\text { area(URMD) }\end{array}$ & 26.57 & 3.69 \\
\hline $\begin{array}{l}\text { Built Up-Built Up } \\
\text { (Urban)-Recreational(URMD) }\end{array}$ & 0.06 & 0.01 \\
\hline $\begin{array}{l}\text { Built Up-Built Up(Urban)-Rural -Built Up } \\
\text { area (Rural)(URMD) }\end{array}$ & 21.82 & 3.03 \\
\hline $\begin{array}{l}\text { Built Up-Built } \\
\text { Up(Urban)-Transportation(URMD) }\end{array}$ & 0.11 & 0.02 \\
\hline Wastelands-Scrub land-Open scrub(WEHB) & 1.22 & 0.17 \\
\hline Waterbodies-Canal/Drain-Lined(WATR) & 1.11 & 0.15 \\
\hline Waterbodies-Lakes/ponds-Dry(WATR) & 0.03 & 0 \\
\hline Waterbodies-Lakes/ponds-Perennial(WATR) & 0.06 & 0.01 \\
\hline Waterbodies-River/Stream-Dry(WATR) & 0.42 & 0.06 \\
\hline Waterbodies-River/Stream-Perennial(WATR) & 6.9 & 0.96 \\
\hline Wetlands-Inland Manmade(WEHB) & 2.87 & 0.4 \\
\hline Wetlands-Inland Natural(WEHB) & 0.09 & 0.01 \\
\hline TOTAL & 719.67 & 100 \\
\hline
\end{tabular}

\section{LITERATURE REVIEW}

SWAT (Soil and water assessment tool) is one of the latest models that was jointly developed by USDA-ARS and the Agricultural experiment Station in Temple, Texas [2]. The SWAT majorly computes values for the components like hydrology, crop growth, soil temperature, sedimentation among others. Originated from agricultural model, the SWAT is based physically, deterministic and continuous with a long term simulation. Neitsch et al, mentions daily time steps to estimate the surface runoff with hourly variations. Here, Green Ampt Formula is used by combining with the SCS curve number method.

Francos et al(2005) used the model for Kerava watershed that is situated to South of Finland having area of about $400 \mathrm{~km}^{2}$ [4]. Daily streamflows were modeled in Spruilli et al(2000) for Kentucky watershed using 1996 data to calibrate the model whilst using 1995 data for its evaluation [5].
Table.1. Landuse and Landcover of the Study Area

SWAT uses hydrological cycle that is based over the water balance equation [6] as below:-

$$
S W_{t}=S W_{o}+\sum_{I=1}^{N}\left(R_{\text {day }}-Q_{\text {surf }}-W_{\text {segp }}-Q_{g w}\right.
$$

where Rday is ith day rainfall, SWo is initial soil moisture ( $\mathrm{mm} \mathrm{H2O}$ ), t-time in days, Qsurf is the surface runoff amount on ith day while $E_{a}$ is amount of evaporation on ith day.

Tripathi et al(2000) applied the model to Nag-wan watershed in China with aim to identify sub watersheds critical for effective land management plan development [7]. Besides, Performance of SWAT was tested for the Upper Mississippi River basin in Srinivasan et al(2010) with nearly satisfactory results [8]. Mathematical models for evaluation of hydrology data is nowadays a trend along with an efficient Remote sensing and GIS monitoring of these parameters. Define abbreviations and acronyms the first time they are used in the text, even after they have been defined in the abstract. Abbreviations such as IEEE, SI, MKS, CGS, sc, dc, and rms do not have to be defined. Do not use abbreviations in the title or heads unless they are unavoidable.

\section{RESULTS AND DISCUSSIONS}

The SWAT model calibrated for the chosen time interval was $1 / 01 / 2005$ to $1 / 01 / 2010$. The rainfall data was collected from IMD (Indian meteorological department), Pune, India. The SWAT model run for the intervals of 1 year for each of the 5 years and the resultant output was generated for runoff per year of SWAT simulation. The predicted runoff by SWAT model is shown in the Table.2

Table.2. Predicated Runoff simulation by SWAT model

\begin{tabular}{|c|c|c|}
\hline Year & Precipitation(mm) & $\begin{array}{c}\text { Surface } \\
\text { Runoff(mm)(Predicted by } \\
\text { SWAT) }\end{array}$ \\
\hline $\begin{array}{c}200 \\
5\end{array}$ & 716 & 185.01 \\
\hline $\begin{array}{c}200 \\
6\end{array}$ & 1369 & 479.54 \\
\hline $\begin{array}{c}200 \\
7\end{array}$ & 1879.4 & 710.05 \\
\hline $\begin{array}{c}200 \\
8\end{array}$ & 1858.2 & 694.73 \\
\hline $\begin{array}{c}200 \\
9\end{array}$ & 1429 & 521.76 \\
\hline
\end{tabular}

a) Comparison of The Data with The CWC Data Obtained at Sripalpur During 2005-10 Interval

The observed discharge data for the watershed at the outlet of Sripalpur was used for the validation of the model. The predicted surface runoff by SWAT model was compared by the observed surface runoff. It shows in the Table No. 3. It shows that difference in computed and observed runoff is minimal. The Average Change in surface runoff computed to runoff in real time conditions was approximately $10.84 \%$ only. It can be shown in Fig. 5. The comparative plot of the observed and predicted surface runoff by SWAT Model.

The measured annual discharge of the study area can be converted to the surface runoff in $\mathrm{mm}$.

Published By:

Blue Eyes Intelligence Engineering and Sciences Publication

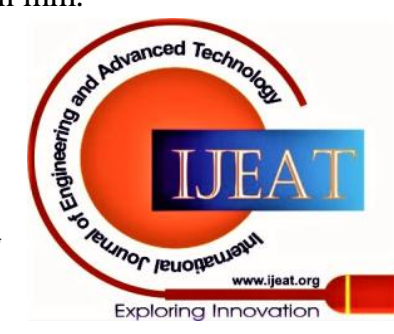




\section{Hydrological Simulation of Runoff for a Watershed in Punpun Basin using SWAT}

Therefore, using the given formula for runoff, the values of surface runoff can be computed from the observed discharges in the basin.

$$
R_{d}(\mathrm{~mm})=\frac{86.4 x Q_{d}}{\operatorname{Area}\left(\mathrm{km}^{2}\right)}
$$

Table.3. Validation of the SWAT Model by Comparison of the Data

\begin{tabular}{|l|l|l|l|l|}
\hline Year & $\begin{array}{l}\text { Observed } \\
\text { Discharg } \\
\text { e of the } \\
\text { Study } \\
\text { Area } \\
\text { (Cumecs) }\end{array}$ & $\begin{array}{l}\text { Observed } \\
\text { Surface } \\
\text { Runoff(mm } \\
\text { Cund }\end{array}$ & $\begin{array}{l}\text { Predicte } \\
\text { d Surface } \\
\text { Runoff } \\
\text { (mm) by } \\
\text { SWAT }\end{array}$ & $\begin{array}{l}\text { Difference } \\
\text { in } \\
\text { Percentage } \\
(\%)\end{array}$ \\
\hline $\begin{array}{l}200 \\
5\end{array}$ & 1416.67 & 170.2 & 185.01 & 8.89 \\
\hline $\begin{array}{l}200 \\
6\end{array}$ & 3750 & 450 & 479.54 & 7.5 \\
\hline $\begin{array}{l}200 \\
7\end{array}$ & 5666.67 & 602.4 & 710.05 & 11.76 \\
\hline $\begin{array}{l}200 \\
8\end{array}$ & 5000 & 600.82 & 694.73 & 15.67 \\
\hline $\begin{array}{l}200 \\
9\end{array}$ & 3996 & 465 & 521.76 & 10.4 \\
\hline
\end{tabular}

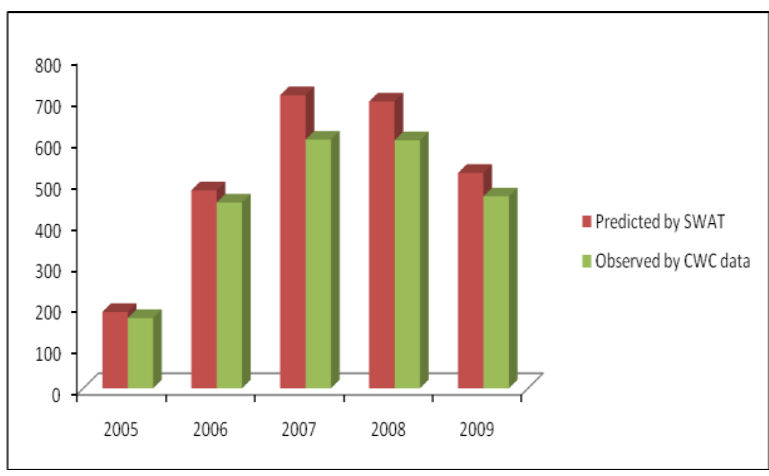

Fig.5. Comparative Plot of Observed and Predicted Surface Runoff by SWAT

\section{CONCLUSIONS}

The model was run and validated with the observed runoff and for the years 2005-2010. The performance of the model was evaluated using statistical and graphical methods to assess the capability of the model in simulating the surface runoff from the study area. The SWAT model was applied to a small watershed of area 720 square kilometers in Punpun Basin, Bihar for the estimation of Surface Runoff According to the model, in the year 2007 the value of the surface runoff was $710 \mathrm{~mm}$, which was maximum and the was minimum for the year 2005 was $185 \mathrm{~mm}$ shown in Table.3. The average value for the observed runoff calculated through discharge data for the basin was $457 \mathrm{~mm} /$ year and the calculated value through SWAT was $518 \mathrm{~mm} /$ year and was difference by $10.84 \%$. As per the observed values of discharge from the CWC, the values for surface runoff for these years were different by about 10 to $11 \%$. The comparison is depicted in Table 3 and Figure 5. It shows that SWAT model is valid for small watersheds in predicting surface runoff for a shorter span and can be used further in estimation of runoff for a longer period. Prediction of runoff and soil loss is important for assessing soil erosion hazards, and for determining suitable land uses and soil conservation measures for a catchment. In such flood prone areas In turn, this can help in deriving optimum benefit from the use of the land while minimizing the negative impacts of land degradation and other environmental problems. As there are limited data available from the region of study, the model developed may have future scope assessing different land management options and in studying the effect of climate change on soil erosion.

\section{REFERENCES}

1. O. N. Dhar and S. Nandargi, "Hydrometeorological Aspects of Floods in India," no. 1994, pp. 1-33, 2003.

2. D. K. Borah, "SWAT Model Background and Application Reviews," vol. 0300, no. 02, 2003.

3. N. D. Liem and N. K. Loi, "Assessing water discharge in be river basin , Vietnam," 2012.

4. Francos, "Hydrological and Water Quality Modelling in a Medium-sized Coastal Basin,” Phys. Chem. Earth (B), Vol. 26, No. 1, pp. 47-52, 2001, vol. 26, no. 1, pp. 47-52, 2001.

5. C. A. Spruill and S. R. Workman, "Simulation of Daily and Monthly Stream Discharge from Small Watersheds Using the SWAT Model," 2000.

6. S. Kumar, H. Ashish, and P. Prabin, "Application of SWAT in an Indian river basin for modeling runoff, sediment and water balance," Environ. Earth Sci., vol. 2025, 2017.

7. M. P. Tripathi, R. K. Panda, and N. S. Raghuwanshi, "Development of effective management plan for critical subwatersheds using SWAT model," vol. 826, no. December 2001, pp. 809-826, 2005.

8. J. G. Arnold, R. Srinivasan, R. S. Muttiah, and J. R. Williams, "LARGE AREA HYDROLOGIC MODELING AND ASSESSMENT PART I: MODEL DEVELOPMENT ' ( Sugawara et al ., 1976 ); HEC-1 ( Hydrologic Engineering Center, 1981 )," vol. 34, no. 1, pp. 73-89, 1998.

\section{AUTHORS PROFILE}

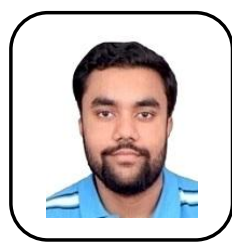

Aditya Shekhar, Postgraduate from the Indian Institute of Technology (IIT) Kanpur with research domain as Environmental Engineering. Completed Bachelors in Engineering (B.E) from Birla Institute of Technology (BIT), Mesra, Ranchi. During B.Tech completed the project work on SWAT modeling using QSWAT for estimation of surface runoff of Punpun basin watershed. Research in the Master's based on chromium remediation and detection for groundwater in Rania district, Uttar Pradesh. Member of the International Association of Hydrogeologists (IAH). Research interests include Groundwater modeling and remediation and Surface water modeling.

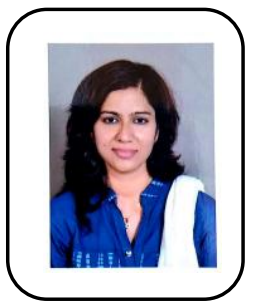

Dr. Subha Sinha, Assistant Professor, Civil Engineering Department, M.I.T. Muzaffarpur, Bihar, India. Research area: Rainfall -Runoff Modeling, ANN, Remote Sensing and GIS, SCS, SWAT, Solid waste management, AHP, multicriteria evaluation, concrete etc. Work Experience: Worked at B.I.T. Mesra, Patna Campus from $16^{\text {th }}$ July 2008 to $15^{\text {th }}$ January 2018 as a Asst. Professor. Working at M.I.T. Muzaffarpur, Bihar from $27^{\text {th }}$ January 2018 as a Asst. Professor.

2014 May: Ph.D. in Water Resources Management from BRA Bihar University, Muzaffarpur.

2006 June: Master of Engineering in Water resources Management from Gujarat university, Ahmedabad, passed with an aggregate of 70\%. 2004 June: Bachelor of Civil Engineering from Saurashtra university Morbi, passed in first with distinction of $66.11 \%$.

Details of publications:

International Journal of Research in Engineering and Social Sciences, ISSN, 2249-9482, Impact Factor: 5.343, Volume 5 Issue 5, May 2015 "Rainfall-Runoff Modeling of Punpun basin using ANN - A case study," 32-40

Presented/Participated paper titled "Effect of blast induced ground motion to structures near mine area incorporating soil structure interaction" on $16^{\text {th }}$ and $17^{\text {th }}$ February, 2018 in National Conference held at Birla Institute of Technology Patna Campus.

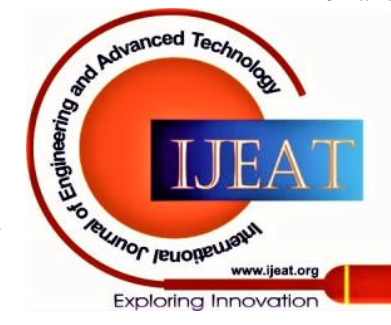


Presented/ Participated paper titled "Sustainable Low-Cost Housing using Cost Effective Construction Technology "Rat Trap Bond Masonry" and "Filler Roof Slab" in Bihar" National Conference on Infrastructure Development and Environmental Assessment (IDEA-2019) from 22 to 24 October 2019 in Gaya.

Presented/Participated paper titled "Suitability Analysis for Solid Waste Disposal Site Using Multi Criteria Evaluation -AHP \& GIS: A case study of the proposed greater Patna master paln-2031 on 16th July,2017 in an International Research conference held at Indian Federation of United Nation Associations.

Presented/Participated in National conference on Recent Advances in Civil Engineering, NIT Patna, Bihar, June 13-14,2013 "Rainfall Runoff modeling by SCS method using RS and GIS,"138-145.

International Journal of Advancement in Structural Engineering, Materials, Design and Testing, Volume 5, 2015, ISBN:978-9-38-489871-7 "MixDesign of Concrete with Blood as an Air- Entraining Agent," 4657-4664.

Delivered an invited talk on "Domestic water portability of Ganga river water in Bihar" in the Engineering Science Section of the 6th \& 7th Bihar Vigyan Congress on 18-02-2017, held at Indira Gandhi Science ComplexPlanetarium, Patna.

Worked as speaker in two days seminar on "Recent Advances in the fluid flow though porous media" organized by the department of applied science \& humanities, Rjkiya Engineering College, Mainpuri,,U.P. from $13^{\text {th }}-14^{\text {th }}$ September 2019.

Associate Member of the Institution of Engineers (INDIA).

Reviewer of series A journal of Institution of Engineers.

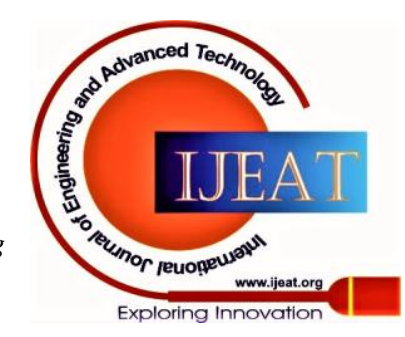

